\title{
Peranan Amelioran Pupuk Organik terhadap Hasil Padi pada Musim Tanam Kedua di Lahan Kering Ngawen Gunungkidul Daerah Istimewa Yogyakarta
}

\author{
Arif Anshori $^{1 *}$, Agung Iswadi ${ }^{1}$, Sunarya $^{2}$ dan Damasus Riyanto ${ }^{1}$ \\ ${ }^{1}$ Balai Pengkajian Teknologi Pertanian (BPTP) Yogyakarta, Indonesia; ${ }^{2}$ Balai Penyuluhan Pertanian (BPP) \\ Gunungkidul, Daerah Istimewa Yogyakarta, Indonesia
}

Diterima: 25 Januari 2021; Disetujui: 11 Maret 2021

\begin{abstract}
Abstrak
Pertanaman padi pada musim tanam kedua di lahan kering Gunungkidul Daerah Istimewa Yogyakarta memerlukan irigasi tambahan dan perbaikan sifat tanah terkait kemampuan menahan air. Penelitian ini bertujuan untuk mengetahui peranan amelioran pupuk organik terhadap hasil padi pada musim tanam kedua di lahan kering. Penelitian dilaksanakan di Dusun Sambirejo Watusigar Ngawen Gunungkidul Daerah Istimewa Yogyakarta pada musim tanam ke dua bulan Maret sampai Juli tahun 2019. Penelitian menggunakan Rancangan Acak Kelompok Lengkap dengan 3 perlakuan berupa tanpa amelioran, amelioran 2 ton ha ${ }^{-1}$ dan amelioran 4 ton ha $^{-1}$, dengan 5 ulangan. Hasil penelitian menunjukkan pemakaian amelioran 2 ton ha ${ }^{-1}$ menghasilkan padi 5,64 ton ha ${ }^{-1}$ dan amelioran 4 ton ha ${ }^{-1}$ menghasilkan padi 6,04 ton $\mathrm{ha}^{-1}$, secara nyata lebih tinggi dari pada tanpa amelioran yang hanya menghasilkan padi 5,29 ton ha $^{-1}$.
\end{abstract}

Kata kunci: amelioran; lahan kering; pupuk organik

\section{The Role of Organic Fertilizer Ameliorants on Rice Yields during Second Growing Season in Dry Land at Ngawen Gunungkidul Special Region of Yogyakarta}

\begin{abstract}
Rice cultivation in the second growing season in dry land at Gunungkidul Special Region of Yogyakarta requires additional irrigation and improvement of physical, chemical and biological soil properties. This study aimed to determine the role of organic fertilizer ameliorant on rice yields during second growing season in dry land. The research was conducted in Sambirejo Watusigar Ngawen Gunungkidul Special Region of Yogyakarta during second growing season from March to July 2019. The study used a Randomized Completely Block Design (RCBD) with 3 treatments in the form of no ameliorant, ameliorant of 2 tons $h^{-1}$ and ameliorant 4 tons $h^{-1}$, with 5 replications. The results showed that the use of ameliorant 2 tons $\mathrm{ha}^{-1}$ produced rice 5.64 ton hal and ameliorant 4 tons $\mathrm{ha}^{-1}$ produced rice 6.04 ton $\mathrm{ha}^{-1}$, which was significantly higher than without ameliorant which only produced 5.29 ton $\mathrm{ha}^{-1}$ of rice.
\end{abstract}

Keywords: ameliorant; dry land; organic fertilizer

\footnotetext{
* Corresponding author: arifanshori@yahoo.com

Cite this as: Anshori, A., Iswadi, A., Sunarya, \& Riyanto, D. (2021). Peranan Amelioran Pupuk Organik terhadap Hasil Padi pada Musim Tanam Kedua di Lahan Kering Ngawen Gunungkidul Daerah Istimewa Yogyakarta. AgriHealth: Journal of Agri-food, Nutrition and Public Health, 2(1), 1-7. doi: http://dx.doi. org/10.20961/agrihealth.v2i1.48067
} 


\section{PENDAHULUAN}

Gunungkidul didominasi oleh lahan kering (Badan Pusat Statistik Kabupaten Gunungkidul, 2019). Permasalahan utama lahan kering adalah keterbatasan air (Brontowiyono et al., 2013), hanya mengandalkan air hujan (Sutrisno, 2016), sehingga peka terhadap kekeringan (Haryati, 2011). Lahan kering memiliki tingkat kesuburan tanah rendah (Abdurachman et al., 2008) dan mudah terdegradasi (Efendi dan Suwardi, 2009). Lahan kering memiliki kandungan bahan organik tanah rendah (Rahman dan Dariah, 2008).

Lahan kering terdiri atas lahan kering masam luas 62,6 juta hektar $(68,1 \%)$ dan lahan kering iklim kering luas 7,8 juta hektar $(8,5 \%)$ (Lakitan dan Gofar, 2013) berpotensi dikembangkan untuk mendukung pembangunan pertanian (Hidayat dan Mulyani, 2005). Lahan kering di Gunungkidul Daerah Istimewa Yoyakarta berupa lahan tegal/kebun seluas 64.536 ha $(88,93 \%)$ (Badan Pusat Statistik Kabupaten Gunungkidul, 2019), berpotensi sebagai solusi peningkatan produksi padi. Penanaman padi dilakukan pada musim tanam kedua dan harus didukung irigasi tambahan. Pada musim tanam pertama petani sudah terbiasa menanam padi secara monokultur atau ditanam tumpang sari dengan jagung (Anshori et al., 2020).

Pertanaman padi pada musim tanam kedua di lahan kering Gunungkidul memerlukan irigasi tambahan dan perbaikan sifat tanah terkait kemampuan menahan air. Menurut Anshori (2020) irigasi tambahan dapat berasal dari dam parit, sungai, sumur dangkal, sumur dalam atau air embung dan diberikan ketika curah hujan tidak mencukupi bagi tanaman padi. Perbaikan sifat tanah terkait kemampuan menahan air dapat dilakukan dengan memberikan pupuk organik sebagai amelioran, yang sekaligus berfungsi sebagai sumber hara (Thangarajan et al., 2013; Hartatik et al., 2015).

Pupuk organik meningkatkan produktivitas tanaman (Adiningsih et al., 1988), meningkatkan kapasitas memegang pupuk, sehingga tidak hilang dari lingkungan perakaran (Adiningsih, 1992). Pupuk organik penting bagi kesubutan fisik, kimia dan biologi tanah (Rosmarkam dan Yuwono, 2002; Hartatik et al., 2015). Pupuk organik lebih mampu menyerap air, meningkatkan hara dalam tanah serta membangun lingkungan sesuai bagi mikroorganisme tanah (Stevenson, 1982; Sutanto, 2002; Sutanto, 2005; Agus, 2012).
Pertanaman padi pada musim tanam kedua di lahan kering Gunungkidul memerlukan irigasi tambahan dan perbaikan sifat tanah terkait kemampuan menahan air agar memberikan produktivitas tanaman yang tinggi. Pertanaman padi pada musim tanam kedua di lahan kering Ngawen Gunungkidul Daerah Istimewa didukung irigasi tambahan asal dam sungai. Penelitian ini bertujuan untuk mengetahui peranan amelioran pupuk organik terhadap hasil padi pada musim tanam kedua di lahan kering.

\section{BAHAN DAN METODE}

Penelitian untuk mengetahui peranan amelioran pupuk organik terhadap hasil padi pada musim tanam kedua dilaksanakan di lahan kering Dusun Sambirejo Desa Watusigar Kecamatan Ngawen Kabupaten Gunungkidul Provinsi Daerah Istimewa Yogyakarta pada bulan Maret sampai Juli tahun 2019. Pada musim tanam ke dua, curah hujan mulai berkurang, petani biasa menanam palawija atau sayuran. Irigasi asal dam sungai dimanfaatkan untuk mendukung pertanaman padi. Komponen teknologi pertanaman padi pada musim tanam kedua di lahan kering Ngawen Gunungkidul meliputi varietas unggul Inpari 19, benih bersertifikat, tanam kurang dari 20 hari setelah sebar, cara tanam tajarwo $2: 1$, olah tanah, pemupukan organik 2 ton ha ${ }^{-1}$ dan anorganik urea $100 \mathrm{~kg} \mathrm{ha}^{-1}$ dan NPK $200 \mathrm{~kg} \mathrm{ha}^{-1}$, pengairan, pengendalian organisme pengganggu tanaman serta panen dan pascapanen (Anshori et al., 2020). Pupuk organik merupakan kompos kotoran sapi dengan nilai $\mathrm{C} / \mathrm{N}$ kurang dari 20. Komponen teknologi tersebut diterapkan untuk mendukung pertanaman padi pada musim tanam kedua.

Amelioran pupuk organik ditambahkan sebagai perlakuan, yang terdiri dari tanpa pemakaian amelioran (kontrol), amelioran 2 ton ha $^{-1}$ dan amelioran 4 ton ha ${ }^{-1}$ diulang sebanyak 5 kali menggunakan lahan atau petak petani yang berbeda, berbentuk Rancangan Acak Kelompok Lengkap (RAKL) dengan 3 perlakuan dan 5 ulangan. Ubinan 2,5 $\mathrm{m}$ x 2,5 m digunakan untuk menentukan produktivitas padi dan jerami. Data curah hujan digunakan untuk memvisualisasi pola tanam. Penelitian tinggi muka air setelah penyiraman digunakan untuk menentukan kondisi air di lahan, selanjutnya sebagai salah satu dasar pengairan tanaman padi. Data curah hujan diperoleh dari Balai 
Penyuluhan Pertanian Ngawen Gunungkidul. Data dianalisis menggunakan SPSS. Perlakuan yang signifikan ditentukan dengan uji $F$, selanjutnya Uji Jarak Berganda Duncan (DMRT) untuk mengetahui pengaruh interaksi perlakuan terhadap estimasi Beda Nyata Terkecil (BNT) pada taraf signifikansi $<0,05$ sesuai dengan Steel and Torie (1978).

\section{HASIL DAN PEMBAHASAN}

Pola tanam petani Ngawen Gunungkidul padi/jagung/kacang tanah-padi/jagung/kacang tanah-jagung/kacang tanah/sayuran-kacang tanah/sayuran/bero, sebagian kecil petani menanam kedelai, kacang hijau atau sayuran (Anshori et al., 2020). Pola tanam petani berdasarkan pengalaman masa lalu, yang menurut
Mujiyo et al. (2020) sangat ditentukan oleh tingkat kesesuaian terhadap kondisi agroklimat. Wisnubroto (1999) menyebutkan upaya ini tergolong sebagai adaptasi petani terhadap kondisi iklim atau curah hujan.

Pembangunan sarana irigasi dam sungai pada tahun 2018 memberikan sumber air tambahan setelah curah hujan. Sarana irigasi dam sungai sebagai sumber irigasi tambahan memberikan pilihan komoditas pertanian kepada petani (Anshori et al., 2021). Padi yang semula hanya ditanam pada musim tanam pertama dengan mengandalkan murni curah hujan, dengan dukungan irigasi tambahan asal dam sungai petani dapat menanam padi pada musim tanam ke dua. Pola tanam petani setelah adanya irigasi tambahan asal dam sungai dapat dilihat pada Gambar 1.

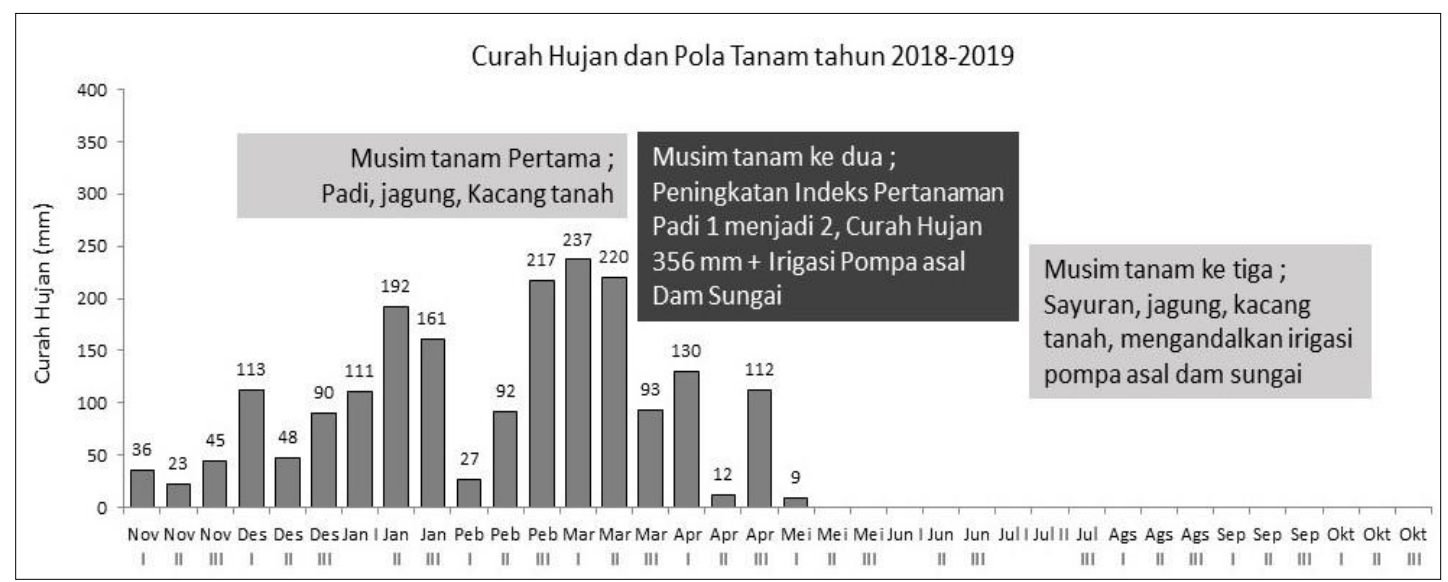

Gambar 1. Curah hujan dasarian dan pola tanam tahun 2018-2019 memanfaatkan irigasi tambahan asal dam sungai

Pada musim tanam ke dua curah hujan turun pada 5 dasarian, besar curah hujan variatif tiap dasarian, dengan total curah hujan $356 \mathrm{~mm}$. Besarnya curah hujan tersebut tidak mencukupi untuk kebutuhan pertumbuhan dan perkembangan tanaman padi. Kekurangan air dipenuhi dari irigasi tambahan asal dam sungai, dengan sistem pompa.

Data dukung berupa infiltrasi air pada tinggi genangan $20 \mathrm{~cm}$ digunakan sebagai salah satu dasar dalam menentukan pemberian air irigasi. Infiltrasi dicatat berdasarkan ketinggian muka air di lahan selama 24 jam, dapat dilihat pada Gambar 2.

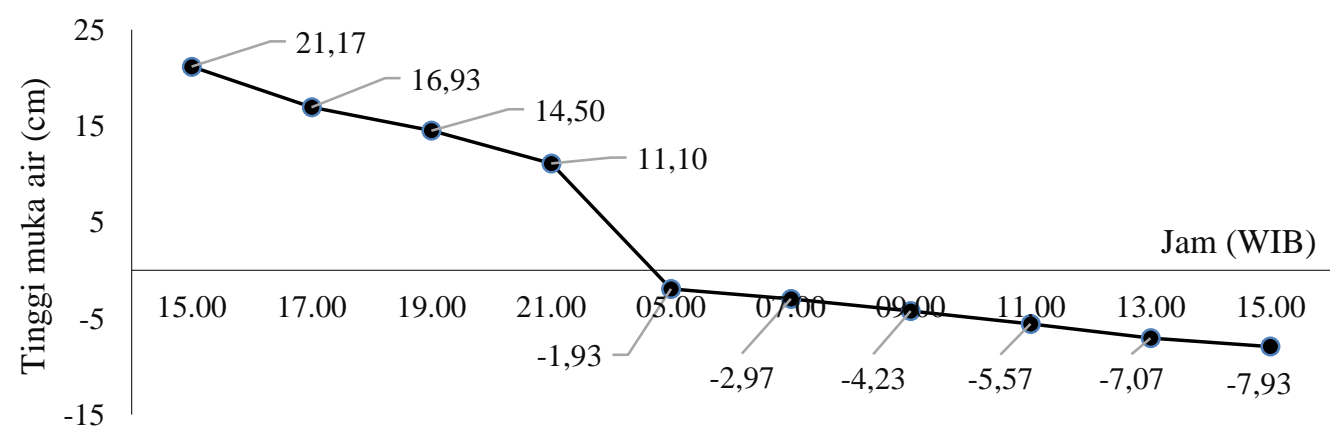

Gambar 2. Tinggi muka air pada percobaan pemberian genangan $20 \mathrm{~cm}$ selama 24 jam 
Genangan $20 \mathrm{~cm}$ mencapai $0 \mathrm{~cm}$ (tanpa genangan) setelah 14 jam, dan mencapai kedalaman $8 \mathrm{~cm}$ setelah 10 jam berikutnya. Selama pengukuran tidak terjadi hujan. Pemberian air setiap rata-rata 5 hari, dengan ketinggian genangan $20 \mathrm{~cm}$, cukup untuk pertumbuhan dan perkembangan tanaman padi. Kadar lengas tanah tidak kurang dari $\mathrm{pF} 4,2$ atau titik layu permanen. Irigasi dari dam sungai cukup untuk mendukung pertanaman padi pada musim tanam kedua.

Produktivitas gabah dan jerami padi meningkat secara nyata $(\mathrm{P}<0,05 ; \mathrm{n}=15)$ dengan pemberian amelioran pupuk organik, berbeda secara nyata pada ketiga perlakuan. Tanpa amelioran produktivitas gabah kering panen Inpari 19 sebesar 5,29 ton ha ${ }^{-1}$, meningkat secara nyata dengan pemberian amelioran 2 ton $\mathrm{ha}^{-1}$ sebesar 5,64 ton ha ${ }^{-1}$ dan selanjutnya meningkat secara nyata dengan pemberian amelioran 4 ton ha $^{-1}$ sebesar 6,04 ton ha' ${ }^{-1}$. Produktivitas jerami kering tanpa amelioran sebesar 4,47 ton ha- ${ }^{-1}$, meningkat secara nyata dengan pemberian amelioran 2 ton $\mathrm{ha}^{-1}$ sebesar 5,39 ton ha- ${ }^{-1}$ dan selanjutnya meningkat secara nyata dengan pemberian amelioran 4 ton ha $^{-1}$ sebesar 6,01 ton $\mathrm{ha}^{-1}$. Produktivitas gabah kering panen dan jerami kering padi varietas Inpari 19 pada musim tanam kedua di lahan kering Ngawen Gunungkidul dapat dilihat pada Gambar 3.

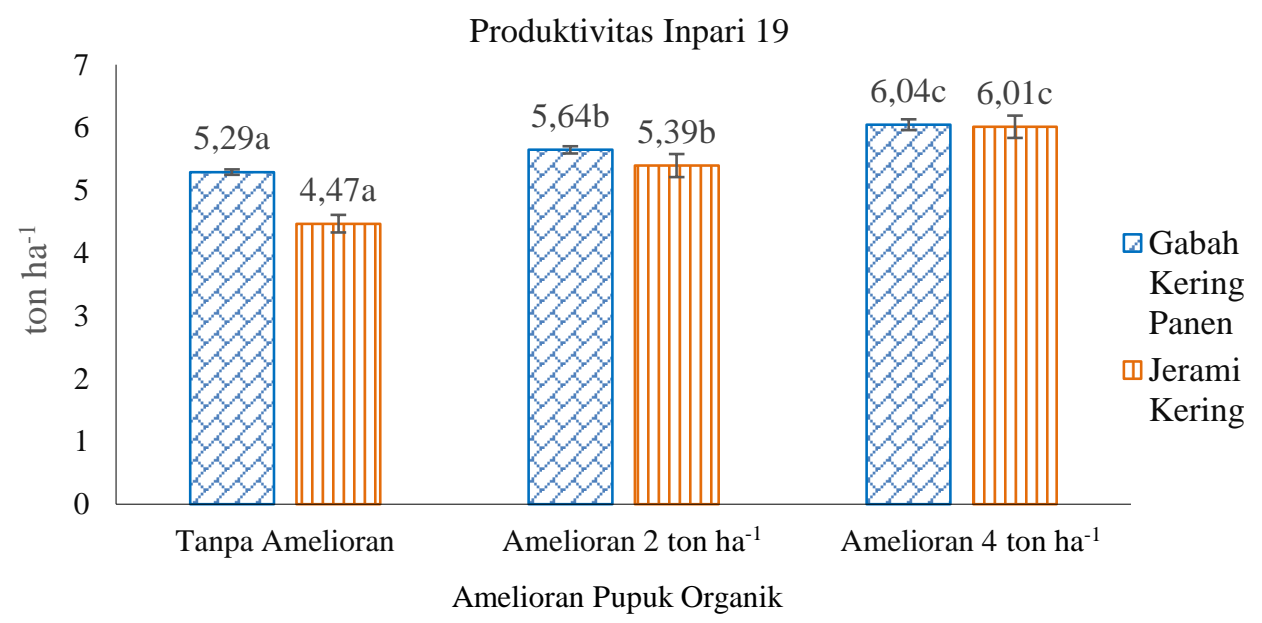

Keterangan: Angka pada parameter pengukuran sama diikuti notasi huruf berbeda menunjukkan berbeda secara nyata berdasarkan uji DMRT taraf 5\%

Gambar 3. Produktivitas gabah kering panen dan jerami kering padi varietas Inpari 19 dengan penambahan amelioran pupuk organik

Pupuk organik memperbaiki sifat tanah (Stevenson, 1982), meningkatkan pertumbuhan dan produktivitas tanaman (Magdoff and van Es, 2009). Pupuk organik sebagai sumber karbon (Cameron et al., 2013), sumber hara tanah (Thangarajan et al., 2013) dan meningkatkan kesehatan tanah (Turmuktini et al., 2012). Amelioran pupuk organik meningkatkan hasil padi pada musim tanam ke dua di lahan kering.

Analisis usaha tani menunjukkan bahwa pertanaman padi pada musim tanam kedua di lahan kering Ngawen Gunungkidul didukung irigasi pompa asal dam sungai dan pemberian amelioran pupuk organik masih memberikan keuntungan bagi petani. Nilai B/C positif menunjukkan bahwa usaha tani layak untuk dijalankan (Soekartawi, 1995; Priatmojo et al., 2019), dapat dilihat pada Tabel 1.

Pemberian amelioran pupuk organik meningkatkan produksi gabah, penerimaan dan keuntungan petani. Namun, penyediaan bahan amelioran meningkatkan komponen biaya usaha tani. Menurut Sudrajat (2020) pendapatan petani dipengaruhi oleh tingkat kelayakan usaha tani. Penjualan gabah merupakan komponen pokok penerimaan dalam usaha tani (Ningrum dan Effendy, 2020). Komponen biaya usaha tani meliputi tenaga kerja (Simatupang, 2006), bahan serta biaya khusus untuk penyiraman.

Tidak semua petani menerima komponen teknologi penyiraman dan pemakaian pupuk organik (Anshori et al., 2020). Biaya menjadi 
pembatas penyiraman, terutama bagi petani kecil dengan luas lahan sempit yang hanya mengandalkan penghasilan dari usaha taninya. Biaya usaha tani cenderung dialihkan untuk keperluan keluarga. Ketersediaan pupuk organik terbatas. Jerami sebagai sumber pupuk organik terangkut keluar dari wilayah usaha tani sebagai upah panen. Pupuk organik asal kotoran sapi terbatas dan tidak mencukupi untuk luas areal lahan pertanian. Pemakaian pupuk organik untuk meningkatkan hasil padi memerlukan penanganan lebih lanjut.

Tabel 1. Analisis usaha tani padi pada musim tanam kedua di lahan kering Ngawen Gunungkidul

\begin{tabular}{|c|c|c|c|}
\hline \multirow[t]{2}{*}{ Komponen } & $\begin{array}{c}\text { Tanpa Amelioran } \\
0 \text { ton } \mathrm{ha}^{-1} \\
\end{array}$ & $\begin{array}{c}\text { Amelioran } \\
2 \text { ton } \mathrm{ha}^{-1}\end{array}$ & $\begin{array}{l}\text { Amelioran } \\
4 \text { ton ha }^{-1} \\
\end{array}$ \\
\hline & \multicolumn{3}{|c|}{ 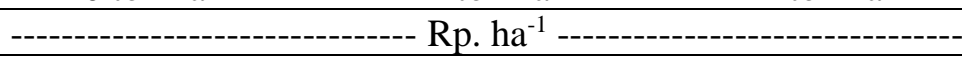 } \\
\hline Bahan (benih, pupuk, pestisida) & 1.940 .000 & 2.740 .000 & 3.540 .000 \\
\hline Tenaga kerja & 4.200 .000 & 4.200 .000 & 4.200 .000 \\
\hline Air irigasi & 3.500 .000 & 3.500 .000 & 3.500 .000 \\
\hline Total Biaya & 9.640 .000 & 10.440 .000 & 11.240 .000 \\
\hline Penerimaan & 22.218 .000 & 23.688 .000 & 25.368 .000 \\
\hline Keuntungan & 12.578 .000 & 13.248 .000 & 14.128 .000 \\
\hline $\mathrm{B} / \mathrm{C}$ & 1,30 & 1,27 & 1,26 \\
\hline
\end{tabular}

\section{KESIMPULAN}

Pemberian amelioran pupuk organik pada pertanaman padi di lahan kering pada musim tanam kedua didukung irigasi tambahan asal dam sungai mampu meningkatkan hasil padi. Teknologi pemberian amelioran dapat diterima petani dan perlu penanganan lebih lanjut terkait dengan ketersediaan pupuk organik..

\section{DAFTAR PUSTAKA}

Abdurachman, A., Dariah, A., \& Mulyani, A. (2008). Strategi dan teknologi pengelolaan lahan kering mendukung pengadaan pangan nasional. Jurnal Litbang Pertanian, 27(2), 43-49. Tersedia dari http://203.190.37.42/ publikasi/p3272081.pdf

Adiningsih, J. S., Rochayati, S., Setyorini, D., \& Sudjadi, M. (1988). Efisiensi penggunaan pupuk pada lahan sawah. Simposium Penelitian Tanaman Pangan II, Puncak, Bogor, 21-23 Maret 1988.

Adiningsih, J. S. (1992). Peranan efisiensi penggunaan pupuk untuk melestarikan swasembada pangan. Orasi Pengukuhan Ahli Peneliti Utama. Jakarta: Pusat Penelitian Tanah dan Agroklimat, Badan Litbang Pertanian, Departemen Pertanian.

Agus, C. (2012). Pengelolaan bahan organik: Peran dalam kehidupan dan lingkungan. Yogyakarta: BPFE UGM.
Anshori, A., Riyanto, D., Sukristiyonubowo, Widodo, S., \& Suradal, S. (2021). The increase of rice cropping index supported by river dam irrigation in dry land. IOP Conference Series: Earth and Environmental Science, 653, 012074. https://doi.org/10.1088/1755-1315/65 3/1/012074

Anshori, A., Riyanto, D., \& Suradal, S. (2020). Peningkatan indeks pertanaman padi pada musim tanam ke dua di Kecamatan Ngawen, Kabupaten Gunungkidul, Provinsi Daerah Istimewa Yogyakarta. AgriHealth: Journal of Agri-Food, Nutrition and Public Health, 1(2), 9-15. https://doi.org/10.20961/agrihealth.v1i2 .42481

Anshori, A. (2020). Strategi peningkatan indeks pertanaman padi di Kabupaten Gunungkidul. Seminar Nasional Pertanian Peternakan Terpadu Ke-3 Universitas Muhammadiyah Purworejo, 238-247. Tersedia dari http:// eproceedings.umpwr.ac.id/index.php/pertania n/article/view/1310

Badan Pusat Statistik Kabupaten Gunungkidul. (2019). Gunungkidul dalam angka. Tersedia dari https://gunungkidulkab.bps.go.id/publica tion/2020/04/27/6830d4504d598ff400524bb1 /kabupaten-gunungkidul-dalam-angka-2020. html

Brontowiyono, W., Lupiyanto, R., Yuwono, E., Sulistiono, B., Handayani, S., \& Harjitoe, D. A. (2013). Rainwater rarvesting based 
marginal land irrigation technology: A case study in Ngawen Sub-district of Gunungkidul Regency Indonesia. International Journal of Sustainable Future for Human Security, 1(2), 63-67. Tersedia dari http://www.j-sustain.com /files/pub/file/Vol1_2_2013/J-SustaiN_Vol1_ No2_63-67_BE_006.pdf

Cameron, K. C., Di, H. J., \& Moir, J. L. (2013). Nitrogen losses from the soil/plant system : a review. Annals of Applied Biology, 162(2), 145-173. https://doi.org/10.1111/aab.12014

Efendi, R., \& Suwardi, S. (2009). Mempertahankan dan meningkatkan produktivitas lahan kering dan produksi jagung dengan sistem penyiapan lahan konservasi. Prosiding Seminar Nasional Serealia, 189-199. Tersedia dari http://balit sereal.litbang.pertanian.go.id/wp-content/uplo ads/2016/12/314.pdf

Hartatik, W., Husnain, \& Widowati, L. R. (2015). Peranan pupuk organik dalam peningkatan produktivitas tanah dan tanaman. Jurnal Sumberdaya Lahan, 9(2), 107-120. Tersedia dari http://ejurnal.litbang.pertanian. go.id/index.php/jsl/article/view/6600

Haryati, U. (2011). Irigasi suplemen dan strategi implementasinya pada pertanian lahan kering. Sinar Tani Edisi 6-12 Juli 2011 No. 3413 Tahun XLI. Badan Litbang Pertanian, pp. 2-11. Tersedia dari http://www. litbang.pertanian.go.id/download/199/file/Irig asi-Suplemen-dan-Strat.pdf

Hidayat, A., \& Mulyani, A. (2005). Lahan kering untuk pertanian. In A. dan Mappaona (Ed.), Teknologi pengelolaan lahan kering тепији pertanian produktif dan ramah lingkungan. Edisi II. Pusat Penelitian dan Pengembangan Tanah dan Agroklimat. Badan Penelitian dan Pengembangan Pertanian. Departemen Pertanian. Hal. 7-38.

Lakitan, B., \& Gofar, N. (2013). Kebijakan inovasi teknologi untuk pengelolaan lahan sub optimal berkelanjutan. Prosiding Seminar Nasional Lahan Suboptimal (Palembang). Tersedia dari https://www.academia.edu/ 7577525/Kebijakan_Inovasi_Teknologi_untu k_Pengelolaan_Lahan_Suboptimal_Berkelanj utan

Magdoff, F., \& van Es, H. (2009). Building soils for better crops: Sustainable soil management (3rd ed). Sustainable Agriculture Research and Education (SARE) program, USDA's National Institute of Food and Agriculture, University of Maryland and University of Vermont. (not italic). Tersedia dari https://www.sare.org/wp-content/uploads /Building-Soils-For-Better-Crops.pdf

Mujiyo, Rahayu, \& Sutopo, N. R. (2020). Implementasi evaluasi lahan untuk pengembangan komoditas tanaman berdasarkan kesesuaian agroklimat. AgriHealth: Journal of Agri-Food, Nutrition and Public Health. 1(2), 62-70. https://doi. org/10.20961/agrihealth.v1i2.44239

Ningrum, N. W., \& Effendy, E. (2020). Analisis pendapatan dan kelayakan usaha tani padi sawah di Desa Laantula Jaya Kecamatan Witaponda Kabupaten Morowali. AGROTEKBIS : E-JURNAL ILMU PERTANIAN, 4(3), 350-355. Tersedia dari http://jurnal.faperta.untad.ac.id/index.php/agr otekbis/article/view/31

Priatmojo, B., Adnyana, M. O., Wardana, I. P., \& Sembiring, H. (2019). Kelayakan finansial dan teknis cara tanam padi jajar legowo super di sentra produksi padi Kawasan Sumatera. Penelitian Pertanian Tanaman Pangan, 3(1), 9-15. https://doi.org/10.21082/jpptp.v3n1.20 19.p9-15

Rahman, A., \& Dariah, A. (2008). Olah tanah konservasi dalam konservasi lahan kering. Jakarta: Balai Penelitian Tanah, Badan Litbang Pertanian, Departemen Pertanian.

Rosmarkam, A., \& Yuwono, N. W. (2002). Ilmu kesuburan tanah. Yogyakarta: Penerbit Kanisius.

Simatupang, J. T. (2006). Analisis kelayakan usaha tani dan tingkat efisiensi pencurahan tenaga kerja pada usaha tani padi sawah. Jurnal Penelitian Bidang Ilmu Pertanian, 4(2), 57-62. Tersedia dari http://repository.usu. ac.id/bitstream/handle/123456789/15553/kptagu2006-\%20\%281\%29.pdf?sequence $=1 \&$ is Allowed=y

Soekartawi. (1995). Analisis usaha tani. Jakarta: UI Press.

Steel, R. G. D., \& Torie, J. H. (1978). Principles and procedures of statistics: Biometrical 
Approach. New York: Mcgraw-Hill (not italic).

Stevenson, F. J. (1982). Humus chemistry: Genesis, composition and reaction. New York: John Willey and Sons.

Sudrajat. (2020). Kelayakan usaha tani padi dan pengaruhnya terhadap pendapatan petani di Desa Margoluwih Kecamatan Seyegan. Majalah Geografi Indonesia, 34(1), 53-62. https://doi.org/10.22146/mgi.54500

Sutanto, R. (2005). Dasar-dasar ilmu tanah: Konsep dan kenyataan. Yogyakarta: Penerbit Kanisius.

Sutanto, R. (2002). Pertanian organik: Menuju pertanian alternatif dan berkelanjutan. Yogyakarta: Kanisius.

Sutrisno, N. (2016). Pengembangan pengelolaan panen hujan mendukung kemandirian pangan. Dalam: Pasandaran, E., Heriawan, R., \& Syakir, M. (Eds.) Sumberdaya lahan dan air : prospek pengembangan dan pengelolaan. IAARD Press.

Thangarajan, R., Bolan, N. S., Tian, G., Naidu, R., \& Kunhikhrisnan, A. (2013). Role of organic amendment application on greenhouse gas emission from soil. Science of the Total Environment, 465, 72-96. https://doi.org/ 10.1016/j.scitotenv.2013.01.031

Turmuktini, T., Kantikowati, E., Natalie, B., Setiawati, M., Yuwariah, Y., Joy, B., \& Simarmata, T. (2012). Restoring the health of paddy soil by using straw compost and biofertilizers to increase fertilizer efficiency and rice production with Sobari (system of organic based aerobic rice intensification) technology. Asian Journal of Agriculture and Rural Development, Asian Economic and Social Society, 2(4), 519-526. http://dx.doi. org/10.22004/ag.econ.197998

Wisnubroto, S. (1999). Meteorologi pertanian Indonesia. Yogyakarta: Mitra Gama Widya. 